\title{
GANGGUAN BAHASA DALAM PERKEMBANGAN BICARA ANAK
}

\author{
Masitoh*) \\ masitohstkipm64@gmail.com \\ Pendidikan Bahasa dan Sastra Indonesia \\ STKIP Muhammadiyah Kotabumi
}

\begin{abstract}
The problem in this article was about the language disorder in the speech development of children. The language disorder on the speech development of children were one of the type of communication disorder that indicate the children who experience the disorders process to use any symbols in language. The language disorder on speech development of children was happened cause there was a disorder on nerves system or abnormalities in related organ that related to the process to use the language and to childrens' speech which occurs due to injury or trauma when they were in prenatal, natal and postnatal. Beside that it could be also caused by the environment at the age of the development of the childrens' language and speech they were did not got a good stimulus. The childrens who experience those difficulties were late in having language development skills. This things could occur in phonology, semantics, and syntax problems so that the childrens was experience the difficulties in transformation that were highly required in communication activities. The handling goals that can be done for the children who had the language disorders in speech development was speech therapy, oral motor, and melody intonation.
\end{abstract}

Keyword: disorder, language, development, speech, children

\section{A. PENDAHULUAN}

Bahasa merupakan sarana untuk berkomunikasi antarmanusia yang berupa simbol bunyi yang dihasilkan oleh alat ucap manusia. Bahasa dianggap sebagai alat yang paling sempurna dan mampu membawakan pikiran dan perasaan, baik mengenai hal-hal yang bersifat konkret maupun abstrak. Sejalan dengan perkembangan ilmu pengetahuan dan teknologi manusia dituntut untuk mempunyai kemampuan berbahasa yang baik. Seseorang yang mempunyai keterampilan berbahasa yang baik akan lebih mudah menyerap dan menyampaikan informasi, baik secara lisan maupun tulis.

Keterampilan berbahasa terdiri atas empat aspek, yaitu menyimak atau mendengarkan, berbicara, membaca, dan menulis. Manusia harus menguasai keempat aspek tersebut agar terampil berbahasa. Salah satu aspek berbahasa yang harus dikuasai adalah berbicara, sebab keterampilan berbicara menunjang keterampilan lainnya (Tarigan, 2008:86). Keterampilan ini bukanlah keterampilan 
yang dapat diwariskan secara turun temurun walaupun pada dasarnya secara alamiah setiap manusia dapat berbicara. Sejalan dengan perkembangan kemampuan serta kematangan jasmani terutama yang bertalian dengan proses bicara, komunikasi tersebut makin meningkat dan meluas. Perkembangan bahasa tersebut selalu meningkat sesuai dengan meningkatnya usia anak.

Perkembangan berbicara pada awal pada anak yaitu menggumam maupun membeo. Seorang bayi dari hari ke hari akan mengalami perkembangan bahasa dan kemampuan bicara, namun tentunya tiap anak tidak sama persis pencapaiannya, ada yang cepat berbicara ada pula yang membutuhkan waktu agak lama. Untuk membantu perkembangannya ibu dapat membantu memberikan stimulasi yang disesuaikan dengan keunikan masingmasing anak. Orang tua sebaiknya selalu memperhatikan perkernbangan tersebut sebab pada masa ini, sangat menentukan proses belajar. Hal ini dapat. dilakukan dengan memberi contoh yang baik, memberikan motivasi pada anak untuk belajar dan sebagainya.

Dalam era moderenisasi seperti saat ini, kita banyak dihadapkan oleh berbagai kasus tentang kelainan atau gangguan berbahasa, salah satu di antaranya adalah gangguan bicara. Gangguan-gangguan tersebut dialami oleh sebagian anak kecil yang usianya masih relatif balita. Gangguan tersebut sering dianggap wajar dan normal. Akan tetapi, orang tua sedikit yang menyadari bahwa anak tersebut mengalami gangguan bicara, dan baru menyadari setelah beranjak dewasa.

Berbagai gangguan yang nampak biasanya terjadi pada umur kurang dari 5 tahun. Saat teman-teman sebayanya sudah bisa mengucapkan kata tertentu dia masih menggumam seperti suara nafas. Seperti contoh anak sudah bisa mengucap beberapa kata, namun diumur tertentu menghilang, termasuk mengoceh dari yang sebelumnya aktif menjadi pasif dan pendiam. Gangguan bicara terdiri dari masalah artikulasi, suara, kelancaran bicara (gagap), afasia (kesulitan dalam menggunakan kata-kata, biasanya akibat cedera otak) serta keterlambatan dalam bicara. Keterlambatan bicara dapat disebabkan oleh berbagai faktor termasuk faktor lingkungan atau hilangnya pendengaran. Gangguan bicara juga berhubungan erat dengan area lain yang mendukung proses tersebut seperti fungsi otot mulut dan fungsi pendengaran. Keterlambatan dan gangguan bisa mulai dari bentuk yang sederhana seperti bunyi suara yang "tidak normal” (sengau, serak) sampai dengan ketidakmampuan untuk mengerti atau menggunakan bahasa, atau ketidakmampuan mekanisme motorik oral dalam fungsinya untuk bicara. 
Jika orang tua tidak paham tentang aktivitas anaknya, akan terjadi keterlambatantan bicara akan sangat fatal. Biasanya orang tua akan menganggap hal itu biasa meskipun perkembangan bicara tiap individu berbeda-beda. Namun, harus diwaspadai apabila anak tersebut mengalami hambatan dalam berbicara. Oleh karena itu, dari penjelasan tersebut dalam artikel ini akan dikemukakan hal-hal sebagai berikut: 1) tahap perkembangan bahasa (berbicara) anak secara umum dan (2) gangguan berbicara dalam perkembangan bicara pada anak. Adapun tujuan dari penulisan artikel ini adalah: (1) untuk mengetahui tahap perkembangan bahasa (berbicara) anak secara umum, (2) untuk mengetahui penyebab dari gangguan bicara dan bahasa, (3) untuk mengetahui gejala dan cara penanganan pada gangguan bicara dan bahasa.

\section{B. GANGGUAN BAHASA DALAM PERKEMBANGAN BICARA \\ ANAK}

Seperti yang telah kita ketahui, proses berbahasa dimulai dengan enkode semantik, enkode gramatikal, dan enkode fonologi. Enkode semantik dan enkode gramatikal berlangsung di dalam otak, sedangkan enkode fonologi dimulai dari otak lalu dilanjutkan pelaksanannya oleh alat-alat bicara yang melibatkan sistem saraf otak (neuromiskuler). Oleh karena itu, dapat dikatakan berbahasa adalah proses mengeluarkan pikiran dan perasaan (dari otak) secara lisan dalam bentuk kata-kata atau kalimat-kalimat (Chaer, 2009:146).

\section{Tahap Perkembangan Bahasa pada Anak}

Perkembangan bahasa terbagi atas dua periode besar, yaitu: periode Pralinguistik (0--1 tahun) dan Linguistik (1-5 tahun). Periode linguistik inilah mulai hasrat anak mengucapkan kata kata yang pertama, yang merupakan saat paling menakjubkan bagi orang tua. Menurut Fatmawati $\quad(2015: 70-71) \quad$ stadia perkembangan awal ujaran pada anak terbagi atas 3 tahap, yaitu: (a) stadia penamaan atau fase satu kata (Holofrase), (b) stadia telegrafis/fase lebih dari satu kata, (c) stadia transformasional dan morfemis/fase diferensiasi. Selanjut Natsir (2017:2-27) menjelaskan bahwa tahapan pemerolehan bahasa anak terbagi atas empat, yaitu: (a) tahap pengocehan (babbling stage), (b) tahap satu kata satu frasa (holophrastic stage), (c) tahap dua kata satu frasa, (d) tahap menyerupai telegram.

a. Stadia/Tahap Pengocehan/Babbling Stage

Pada tahap ini anak telah berumur kira-kira enam bulan, ia mulai mengoceh. Dalam tahap ini anak mengucapkan sejumlah bunyi ujar yang tidak 
bermaknanya dan sebagian kecil menyerupai kata atau penggalan kata yang bermakna karena kebetulan saja. b. Stadia/Tahap Satu Kata atau Holofrase

Pada tahap ini anak mempergunakan satu kata untuk menyatakan pikiran yang kompleks, baik yang berupa keinginan, perasaan atau temuannya tanpa perbedaan yang jelas. Misalnya kata $d u d u k$, bagi anak dapat berarti "saya mau duduk", atau kata kursi , dapat juga berarti "mama sedang duduk". Orang tua baru dapat mengerti dan memahami apa yang dimaksudkan oleh anak tersebut apabila kita tahu dalam konteks apa kata tersebut diucapkan, sambil mengamati mimik (raut muka) gerak serta bahasa tubuh lainnya. Pada umumnya kata pertama yang diurapkan oleh anak adalah kata benda, setelah beberapa waktu barulah disusul dengan kata kerja.

c. Stadia Telegrafis/Tahap Lebih dari Satu Kata

Tahap dua kata muncul pada anak berusia sekitar 18 bulan. Pada fase ini anak sudah dapat membuat kalimat sederhana yang terdiri atas dua atau tiga kata. Kalimat tersebut kadang-kadang terdiri dari pokok kalimat dan predikat, kadang-kadang pokok kalimat dengan objek dengan tata bahasa yang tidak benar. Setelah dua kata, muncullah kalimat dengan tiga kata, diikuti oleh empat kata dan seterusnya. Pada periode ini bahasa yang digunakan oleh anak tidak lagi egosentris, dari dan untuk dirinya sendiri. Mulailah mengadakan komunikasi dengan orang lain secara lancar. Orang tua mulai melakukan tanya jawab dengan anak secara sederhana. Anak pun mulai dapat bercerita dengan kalimatkalimatnya sendiri yang sederhana. d. Stadia Transformasional dan Morfemis (Tahap Diferensiasi)

Tahap terakhir dari masa balita yang berlangsung antara usia dua setengah sampai lima tahun. Keterampilan anak dalam berbicara mulai lancar dan berkembang pesat. Dalam berbicara anak bukan saja menambah kosakatanya yang mengagumkan, tetapi anak mulai mampu mengucapkan kata demi kata sesuai dengan jenisnya, terutama dalam pemakaian kata benda dan kata kerja. Anak telah mampu mempergunakan kata ganti orang "saya" untuk menyebut dirinya, mampu mempergunakan kata dalam bentuk jamak, awalan, akhiran dan berkomunikasi lebih lancar lagi dengan lingkungan. Anak mulai dapat mengkritik, bertanya, menjawab, memerintah, memberitahu dan bentukbentuk kalimat lain yang umum untuk satu pembicaraan "gaya" dewasa.

\section{Faktor-faktor yang Memengaruhi Perkembangan Bahasa Anak}

Pengenalan bahasa yang lebih dini dibutuhkan untuk memperoleh keterampilan bahasa yang baik. Yusuf (2014:153-158) mengatakan bahwa 
perkembangan bahasa dipengaruhi oleh 5 faktor, yaitu: faktor kesehatan, intelegensi, status sosial ekonomi, jenis kelamin, dan hubungan keluarga. Secara rinci dapat diidentifikasi sejumlah faktor yang mempengaruhi perkembangan bahasa adalah sebagai berikut.

\section{a. Kognisi (Proses Memeroleh \\ Pengetahuan)}

Tinggi rendahnya kemampuan kognisi individu akan mempengaruhi cepat lambatnya perkembangan bahasa individu. Ini relevan dengan pembahasan sebelumnya bahwa terdapat korelasi yang signifikan antara pikiran dengan bahasa seseorang.

b. Pola Komunikasi dalam Keluarga.

Dalam suatu keluarga yang pola komunikasinya banyak arah akan mempercepat perkembangan bahasa keluarganya.

c. Jumlah Anak atau Jumlah Keluarga.

Suatu keluarga yang memiliki banyak anggota keluarga, perkembangan bahasa anak lebih cepat karena terjadi komunikasi yang bervariasi dibandingkan dengan yang hanya memiliki anak tunggal dan tidak ada anggota lain selain keluarga inti.

d. Posisi Urutan Kelahiran.

Perkembangan bahasa anak yang posisi kelahirannya di tengah akan lebih cepat ketimbang anak sulung atau anak bungsu. Hal ini disebabkan anak sulung memiliki arah komunikasi ke bawah saja dan anak bungsu hanya memiliki arah komunikasi ke atas saja.

e. Kedwibahasaan (Pemakaian dua bahasa)

Anak yang dibesarkan dalam keluarga yang menggunakan bahasa lebih dari satu atau lebih bagus dan lebih cepat perkembangan bahasanya dari pada yang hanya menggunakan satu bahasa saja karena anak terbiasa menggunakan bahasa secara bervariasi. Misalnya, di dalam rumah dia menggunakan bahasa daerah dan di luar rumah dia menggunakan bahasa Indonesia.

Beberapa hal yang mendukung potensi anak berbicara adalah sebagai berikut.

a. Kematangan alat berbicara. Kemampuan berbicara juga tergantung pada kematangan alat-alat berbicara. Misalnya tenggorokan, langit-langit, lebar rongga mulut dan Iain-lain dapat mempengaruhi kematangan berbicara.

b. Kesiapan berbicara. Kesiapan mental anak sangat bergantung pada pertumbuhan dan kematangan otak. Kesiapan dimaksud biasanya dimulai sejak anak berusia antara 12--18 bulan, yang disebut teachable moment dari perkembangan bicara. Pada saat inilah anak betul-betul sudah siap untuk belajar. bicara yang sesungguhnya.

c. Adanya model yang baik untuk dicontoh oleh anak. Anak dapat 
membutuhkan suatu model tertentu agar dapat melafalkan kata dengan tepat untuk dapat dikombinasikan dengan kata lain sehingga menjadi suatu kalimat yang berarti. Model tersebut dapat diperoleh dari orang lain, misalnya orang tua atau saudara, dari radio yang sering didengarkan atau dari $\mathrm{TV}$, atau aktor film yang bicaranya jelas dan berarti.

d. Kesempatan berlatih. Anak yang kurang mendapatkan latihan keterampilan berbicara akan timbul frustasi dan bahkan sering kali marah yang tidak dimengerti penyebabnya oleh orang tua atau lingkungannya. Pada gilirannya anak kurang memeroleh motivasi untuk belajar berbicara yang pada umumnya disebut "anak ini lamban" bicaranya.

e. Motivasi untuk belajar dan berlatih. Memberikan motivasi dan melatih anak untuk berbicara sangat penting karena untuk memenuhi kebutuhannya dan memanfaatkan potensi anak.

f. Bimbingan. Bimbingan bagi anak sangat penting untuk mengembangkan potensinya. Oleh karena itu, hendaknya orang tua suka memberikan contoh atau model bagi anak, berbicara dengan pelan yang mudah diikuti oleh anak. Bimbingan tersebut sebaiknya selalu dilakukan secara terus menerus dan konsisten.
Selanjutnya dijelaskan langkahlangkah untuk membantu perkembangan bahasa anak adalah sebagai berikut.

a. Membaca. Ketika orang tua membaca, tunjuklah gambar yang ada di buku dan sebutkan nama dari gambar tersebut keras-keras. Mintalah anak untuk menunjuk gambar yang sama dengan yang ada sebutkan tadi. Buatlah kegiatan membaca menjadi menyenangkan dan menarik bagi anak dan lakukanlah setiap hari.

b. Perkenalkan kata-kata baru pada anak setiap hari, dapat berupa nama-nama tanaman, nama hewan ataupun nama makanan yang disiapkan baginya.

c. Cobalah untuk tidak menyelesaikan kalimat anak. Berikan kesempatan baginya untuk menemukan sendiri kata yang tepat yang ingin dia sampaikan.

d. Berbicaralah pada anak setiap hari, dan pandanglah mereka ketika berbicara atau mendengarkan mereka. Biarkan mereka tahu bahwa mereka sangat penting.

Berikut beberapa cara untuk menstimulasi agar perkembangan bicara balita semakin lancar dan ia gemar bicara.

a. Ceritakan kesibukan Anda. Omongkan dengan lantang apa saja yang sedang Anda kerjakan dan lemparkan pertanyaan-pertanyaan untuk balita. “Teruslah bicara walaupun Anda 
tampak konyol karena balita tidak bisa menjawab".

b. Jadi 'role model'. Bila balita Anda mengatakan "cucu" untuk susu, gunakan pengucapan yang benar ketika Anda merespon, "Ini susumu." Kembangkan penguasaan bahasanya dengan menambahkan kata-kata baru, misalnya "Susumu warnanya putih, enak sekali." Strategi ini tak hanya akan menambah jumlah kosa katanya tapi juga mengajarkan cara kombinasi kata.

c. Berlagak "bodoh". Beri balita kesempatan untuk meminta dan mengungkapkan kebutuhannya sebelum anda memberikan padanya. Contohnya, saat bermain, ia menggulirkan bola dan anda tahu ia ingin anda mengembalikan bola itu padanya, pura-pura saja anda tidak mengerti, berikan ekspresi wajah bingung dan bertanya, "Ibu harus apa?" Jeda seperti ini akan menyemangatinya untuk berkomunikasi.

d. Tetap nyata. Hindari untuk mengucapkan kata berlebihan atau berbicara dalam bahasa slang atau bahasa pergaulan yang tidak dimengerti balita usia $1-2$ tahun. Orang tua wajib berbicara dalam kalimat-kalimat reguler dan dalam bahasa yang benar, yang akan membantu anak mengerti cara memadukan kata menjadi kalimat yang bermakna.

\section{Keterlambatan dan Gangguan dalam Perkembangan Bicara Anak}

Tingkat perkembangan bicara seorang anak berada di bawah tingkat kualitas perkembangan bicara umumnya dapat diketahui dari ketepatan penggunaan kosa kata (bahasa) anak tersebut saat bersama teman sebayanya bercakap-cakap/berbicara. Keterlambatan berbicara tidak hanya mempengaruhi penyesuaian akademis dan pribadi anak, pengaruh yang paling serius adalah terhadap kemampuan membaca pada awal anak masuk sekolah. Banyak penyebab keterlambatan bicara pada anak, umumnya adalah: (1) rendahnya tingkat kecerdasan yang membuat anak tidak mungkin belajar berbicara sama baiknya seperti teman-teman sebayanya, yang kecerdasannya normal atau tinggi; (2) kurang motivasi karena anak mengetahui bahwa mereka dapat berkomunikasi secara memadai dari dorongan orang tua/orang dewasa; dan (3) terbatasnya kesempatan praktik berbicara karena ketatnya batasan tentang seberapa banyak mereka diperbolehkan berbicara di rumah.

Salah satu penyebab tidak diragukan lagi paling umum dan paling serius adalah ketidakmampuan mendorong/memotivasi anak berbicara, bahkan pada saat anak mulai berceloteh. Apabila anak tidak 
diberikan rangsangan (stimulasi) didorong untuk berceloteh, hal ini akan menghambat penggunaan di dalam berbahasa/kosa kata yang baik dan benar. Kekurangan dorongan tersebut merupakan penyebab serius keterlambatan berbicara anak terlihat dari fakta bahwa apabila orang tua tidak hanya berbicara kepada anak mereka, tetapi juga menggunakan kosa kata yang lebih luas dan bervariasi Adapun kemampuan anak di dalam berbicara yang berkembang sangat pesat dan cepat yaitu contohnya: anak-anak dari golongan yang lebih atau menengah yang orang tuanya ingin sekali menyuruh mereka (anak) belajar berbicara lebih awal (cepat) dan lebih baik. Sangat kurang kemungkinannya mengalami keterlambatan berbicara pada anak. Anak yang berasal dari golongan yang lebih rendah yang orang tuanya tidak mampu memberikan dorongan tersebut bagi mereka, apakah kekurangan waktu/karena mereka tidak menyadari betapa pentingnya suatu perkembangan bicara pada anak didik tersebut.

\section{Gangguan Berbahasa (Berbicara)}

Gangguan bahasa sering juga disebut sebagai gangguan perkembangan bicara dan bahasa ekspresif. Kelainan atau gangguan bahasa merupakan salah satu jenis kelainan dalam komunikasi dengan indikasi seseorang mengalami gangguan dalam proses simbolis. Kesulitan ini mengakibatkan seseorang tidak mampu untuk memberikan simbol atau lambang yang diterima dan sebaliknya tidak mampu mengubah konsep pengertian menjadi simbol-simbol yang dapat dimengerti oleh orang lain. Jika seseorang tidak dapat berkomunikasi dengan sesamanya secara sempurna, mereka dapat dikatakan mengalami gangguan atau kelainan bahasa. Gangguan bahasa dapat terjadi jika komunikasi seseorang menyimpang jauh dari bahasa yang digunakan oleh anak normal.

\section{Penyebab Gangguan Berbahasa}

Penyebab gangguan bicara dan bahasa sangat banyak dan luas, semua gangguan mulai dari proses pendengaran, penerus impuls ke otak, otak, otot atau organ pembuat suara. Beberapa penelitian menunjukkan penyebab gangguan bicara adalah adanya gangguan hemisfer dominan.

Menurut Efendi yang dikutip Nurhidayati, dkk (2013:4) ada beberapa penyebab gangguan atau keterlambatan bicara adalah sebagai berikut.

\section{a. Faktor Medis}

Faktor medis yang paling banyak berperan dalam kesulitan belajar bahasa adalah tidak atau kurang berfungsinya sistem syaraf pusat yang disebabkan oleh adanya cidera atau memar. Dalam kaitan ini dikenal afasia, yaitu hilangnya kemampuan bicara karena gangguan pada syaraf pusat. Cidera atau memar pada otak dapat terjadi karena berbagai kejadian seperti trauma ketika ibu sedang mengandung, 
penggunaan obat berlebihan, kelahiran muda (premature), benturan fisik, struk, dan keracunan.

b. Kondisi Fisiologis

Yang dimaksud dengan kondisi fisiologis adalah kemampuan dari organorgan yang terkait dalam menjalankan fungsinya untuk mendukung terhadap kelancaran anak dalam meniti tugas perkembangan bicara dan bahasanya. Organ-organ tersebut meliputi susunan syaraf (syaraf senso-motoris ), kondisi organ pendengaran dan organ bicara.

c. Kondisi Lingkungan

Lingkungan keluarga hendaknya menciptakan situasi yang kondusif, untuk memberikan kontribusi positif bagi perkembangan bicara dan bahasa anak. Peran aktif orang tua atau keluarga dalam memberikan stimulasi verbal, dapat mendorong anak untuk lebih meningkatkan kualitas atau kuantitas kemampuan bicara dan bahasanya.

\section{Bentuk Gangguan Berbahasa}

Gangguan bahasa merupakan salah satu bentuk kelainan atau gangguan dalam komunikasi dengan indikasi klien mengalami kesulitan atau kehilangan dalam proses simbolisasi. Kesulitan simbolisasi ini mengakibatkan seseorang tidak mampu memberikan simbol yang diterima dan sebaliknya tidak mampu mengubah konsep pengertiannya menjadi simbol-simbol yang dapat dimengerti oleh orang lain dalam lingkungannya.

Menurut Tarmansyah yang dikutip Nurhidayati, dkk (2013:5-10) "ada bentuk gangguan bahasa diantaranya keterlambatan dalam perkembangan bahasa dan afasia".

1. Keterlambatan dalam Perkembangan Bahasa

Adalah suatu bentuk kelainan bahasa yang ditandai dengan kegagalan klien dalam mencapai tahapan perkembangan bahasanya sesuai dengan perkembangan bahasa anak normal seusianya. Kelambatan perkembangan bahasa di antaranya disebabkan keterlambatan mental intelektual, ketunarunguan, congenital aphasia, nutisme, disfungsi minimal otak dan kesulitan belajar. Anak-anak yang mengalami kesulitan tersebut di atas terlambat dalam kemampuan perkembangan bahasa, dapat terjadi pada fonologis, semantik, dan sintaksisnya, sehingga anak mengalami kesulitan dalam tranformasi yang sangat diperlukan dalam kegiatan berkomunikasi. Selain adanya gangguan transformasi maupun simbolisasi juga disertai gangguan tingkah laku. Gangguan tingkah laku tersebut sangat memengaruhi proses perolehan bahasa di antaranya kurang perhatian dan minat terhadap rangsangan yang ada di sekelilingnya, perhatian yang mudah beralih, konsentrasi yang kurang baik, tampak mudah bingung, cepat putus asa. 
2. Afasia

Afasia adalah satu jenis kelainan bahasa yang disebabkan oleh adanya kerusakan pada pusat-pusat bahasa di Cortex Cerebri. Adanya lesi di pusat-pusat bahasa di Cortex cerebri menyebabkan klien mengalami kesulitan dan atau kehilangan kemampaun dalam simbolisasi baik secara aktif maupun pasif.

Apabila dikaji afasia tersebut secara klinis, dapat dibedakan menjadi beberapa macam, yaitu afasia sensoria, afasia motoris, afasia konduktif, dan afasia amnesik.

a. Afasia Sensoria

Kelainan ini ditandai dengan kesulitan dalam memberikan rangsangan yang diterimanya. Bicara spontan biasanya lancar hanya kadang-kadang kurang relevan dengan situasi pembicaraan atau konteks komunikasi.

b. Afasia Motoris

Istilah lain dari afasia motoris adalah afasia ekspresif nonfluent aphasia, atau Broca Aphasia. Klien yang mengalami afasia motoris kesulitan dalam mengoordinasi atau menyusun pikiran, perasaan dan kemauan menjadi simbolsimbol yang bermakna dan dimengerti oleh orang lain. Suatu hal yang perlu diperhatikan bahwa mereka mengerti dan dapat menginterpretasikan rangsangan yang diterima, hanya untuk mengekspresikan mengalami kesulitan. Jenis afasia motorik bisa terjadi, yaitu dia mengalami kesulitan pada cara menulis/grafis, jenis ini disebut dengan agrafia. Seperti telah diuraikan di atas bahwa kelainan ini dapat dialami baik oleh anak-anak maupun orang dewasa. Hal tersebut terjadi karena adanya kerusakan pada pusat broca di lobus temporalis interior, lobus parietalis interior atau lobus prontalis posterior.

c. Afasia Konduktif

Istilah lain untuk afasia konduktif adalah dynamik aphasia, atau ranscorticak sensory aphasia. Klien ini ditandai dengan kesulitan dalam meniru pengulangan bunyi-bunyi bahasa. Umumnya kemampuan untuk pemahaman rangsangan relatif baik, tetapi kadang-kadang terjadi gangguan. Pada saat berbicara cukup lancar terutama pada kalimat-kalimat pendek, tetapi pada kalimat-kalimat yang lebih panjang kelancarannya terganggu. Afasia ini terjadi disebabkan oleh adanya kerusakan pada fasiculus arcuatus serta di bagian dalam gyrus supramarginal di lobus temporalis superior.

d. Afasia Amnestik

Istilah lain untuk afasia amnestik ini disebut juga nominal afasia, atau anomia. Klien ini ditandai dengan kesulitan dalam memilih dan menggunakan simbol-simbol yang tepat. Umumnya simbol-simbol yang 
sulit dipilih adalah yang berhubungan dengan nama, aktivitas, situasi yang berhubungan dengan aktivitas kehidupan. Afasia ini terjadi karena adanya kerusakan pada gyrus angularis di lobus temporalis kamisfer kiri. Selain keterlambatan perkembangan bahasa dan afasia, juga terdapat beberapa bagian mengenai letak kerusakan syaraf pada anak berkesulitan bahasa.

3. Kelainan Organ Bicara

Kelainan ini meliputi lidah pendek, kelainan bentuk gigi dan mandibula (rahang bawah), kelainan bibir sumbing (palatoschizis/cleft palate), deviasi septum nasi, adenoid atau kelainan laring. Pada lidah pendek terjadi kesulitan menjulurkan lidah sehingga kesulitan mengucapkan huruf [t, n, dan 1]. Kelainan bentuk gigi dan mandibula mengakibatkan suara desah seperti [f, v, s, z, dan th]. Kelainan bibir sumbing bisa mengakibatkan penyimpangan resonansi berupa rinolaliaaperta, yaitu terjadi suara hidung (sengau) pada huruf bertekanan tinggi seperti [m, n, ny, ng, s, k, dan g].

4. Gangguan Pendengaran

Anak yang mengalami gangguan pendengaran kurang mendengar pembicaraan di sekitarnya. Gangguan pendengaran selalu harus dipikirkan bila ada keterlambatan bicara. Ada beberapa penyebab gangguan pendengaran, bisa karena infeksi, trauma atau kelainan bawaan. Infeksi bisa terjadi bila mengalami infeksi yang berulang pada organ dalam sistem pendengaran. Kelainan bawaan biasanya karena kelainan genetik, infeksi ibu saat kehamilan, obat-obatan yang dikonsumsi ibu saat hamil, atau bila terdapat keluarga yang mempunyai riwayat ketulian. Gangguan pendengaran bisa juga saat bayi mengalami infeksi berat, infeksi otak, pemakaian obat-obatan tertentu atau kuning yang berat (hiperbilirubin). Pengobatan dengan pemasangan alat bantu dengar akan sangat membantu bila kelainan ini terdeteksi sejak awal. Pada anak yang mengalami gangguan pendengaran, tetapi kepandaian normal, perkembangan berbahasa sampai 6-9 bulan tampaknya normal dan tidak ada kemunduran. Kemudian menggumam akan hilang disusul hilangnya suara lain dan anak tampaknya sangat pendiam. Adanya kemunduran ini juga seringkali dicurigai sebagai kelainan saraf degeneratif.

5. Gangguan Emosi dan Perilaku Gangguan bicara biasanya menyerta pada gangguan disfungsi otak minimal, gejala yang terjadi sangat minimal sehingga tidak mudah untuk dikenali. 
Biasanya diserta kesulitan belajar, hiperaktif, tidak terampil, dan gejala tersamar lainnya.

6. Autisme

Gangguan bicara dan bahasa yang berat dapat disebabkan oleh autism. Autisme adalah gangguan perkembangan pervasif pada anak yang ditandai dengan adanya gangguan dan keterlambatan dalam bidang kognitif, bahasa, perilaku, komunikasi dan interaksi sosial. Dalam buku Children With Starving Brains karangan Jaquelyn Mecandless menyebutkan bahwa autis merupakan masalah genetika pencernaan dan sistem imun tubuh, invasi virus, jamur dan bakteri patogen lainnya.

\section{Gejala Gangguan Berbahasa}

Gejala anak mengalami gangguan berbicara ditinjau dari segi klinis, gejala kelainan bicara dalam hubungannya dengan penyebab kelainannya dapat dibedakan menjadi beberapa jenis.

a. Disaudia

Disaudia dalah satu jenis gangguan bicara yang disebabkan gangguan pendengaran. Bagi anak tunarungu konsep bicara yang digunakan dalam mengadakan interaksi komunikasi dengan lingkungannya, misalnya kata "kopi” ia dengar "topi", kata "bola ia dengar "pola".
Beberapa karakteristik bicaranya adalah terdapat kesalahan pengucapan baik dalam mekanisme pergerakan titik artikulasi maupun dalam pengucapannya. Kesalahan dalam penggunaan fonasi yang berhubungan dengan alat ucap, intensitasnya semakin lama semakin berkurang, nadanya cenderung tinggi tidak jarang mengalami pitch break atau perubahan nada yang terjadi secara tiba-tiba. Umumnya klien disaudia dalam berkomunikasi cenderung menggunakan bahasa isyarat yang telah dikuasainya.

b. Dislogia

Dislogia diartikan sebagai satu bentuk kelainan bicara yang disebabkan karena kemampuan kapasitas berpikir atau taraf kecerdasan yang di bawah normal. Pola kemampuan berpikirnya sederhana dan umumnya terbatas pada objek yang bersifat konkret dan rutin. Rendahnya kemampuan mengingat hal ini juga akan mengakibatkan penghilangan fonem, suku kata atau kata pada waktu pengucapan kalimat. Misalnya "makan" diucapkan "kan”, "ibu memasak di dapur" diucapkan "bu..sak... pur".

c. Distartia 
Distartia diartikan sebagai suatu jenis kelainan bicara yang terjadi akibat adanya kelumpuhan, kelemahan, kekakuan, atau gangguan koordinasi otot alat-alat ucap atau organ bicara sehubungan dengan adanya kerusakan pada susunan saraf pusat ataupun perfier. Kerusakan pada saraf tersebut mempengaruhi pengaturan dan koordinasi alat ucap sehingga pergerakan alat-alat tersebut terganggu dan memengaruhi kemampuan bernafas, fonasi dan terutama kemampuan artikulasi dan resonansi.

\section{d. Disglosia}

Artinya kelainan bicara yang terjadi karena adanya kelainan struktur dari organ bicara yaitu altikulator. Jika dalam proses artikulasi dan resonansi mengalami kegagalan, simbol-simbol bunyi yang dihasilkan menjadi kurang atau bahkan tidak berarti.

\section{e. Dislalia}

Artinya gejala bicara yang disebabkan oleh kondisi psikososial, yaitu yang lebih dominan disebabkan oleh faktor lingkungan dan gejala psikologis. Gejala bicara yang terjadi karena ketidakmampuan klien dalam memperhatikan bunyi-bunyi bicara yang diterima. Dengan demikian, klien tidak dapat membentuk konsep bahasa.

Gejala lain dari dislalia adalah ketidakmampuan klien dalam mengingat rangsang yang diterima. Kesulitan bicara akibat peniruan yang salah dari lingkungannya misal anak mengucapkan "mbah uti" untuk pengertian "mbah putri”, orang tua menguatkannya; "mbah uti di mana Ela?". Peristiwa itu akan berjalan terus dan orang tua tanpa menyadari telah menggunakan pola bicara yang salah.

\section{Penanganan Dalam Gangguan}

\section{Berbahasa}

Penanganan gangguan bicara diawali dengan identifikasi pasien (Sastra, 2011:30) seperti, riwayat kesehatan, kemampuan berbicara, kemampuan mendengar, kemampuan kognitif, dan kemampuan berkomunikasi. Kemudian penanganan dilanjutkan dengan diagnosis gangguan yang dialami pasien. Setelah hasil diagnosis didapat, barulah diterapkan terapi yang tepat untuk pasien.

a. Terapi Bicara. Terapi bicara biasanya menggunakan audio atau video dan cermin. Terapi bicara anak-anak biasanya menggunakan pendekatan bermain, boneka, bermain peran, memasangkan gambar atau kartu. Terapi bicara orang dewasa biasanya menggunakan metode langsung, yaitu melalui latihan dan praktik. Terapi artikulasi pada orang dewasa berfokus untuk membantu pasien agar dapat memproduksi bunyi dengan tepat, meliputi bagaimana menempatkan posisi lidah dengan tepat, bentuk rahang, dan mengontrol nafas agar 
dapat memproduksi bunyi dengan tepat.

b. Terapi Oral Motorik. Terapi ini menggunakan latihan yang tidak melibatkan proses bicara, seperti minum melalui sedotan, meniup balon, atau meniup terompet. Latihan ini bertujuan untuk melatih dan memperkuat otot yang digunakan untuk berbicara.

c. Terapi Intonasi Melodi. Dalam Terapi intonasi melodi kita dapat diterapkan pada penderita stroke yang mengalami gangguan berbahasa. Musik atau melodi yang digunakan biasanya yang bertempo lambat, bersifat lirik, dan mempunyai tekanan yang berbeda.

\section{SIMPULAN}

Dari uraian di atas, dapat disimpulkan bahwa gangguan bahasa dan bicara merupakan salah satu jenis gangguan komunikasi yang diindikasikan mengalami gangguan pada proses simbolisnya. Penyebab pada gangguan bahasa dan bicara sangat lua. Hal tersebut dapat disebabkan adanya gangguan pada sistem sarafnya ataupun kelainan pada organ yang berhubungan pada proses berbahasa dan bicara yang terjadi karena cidera atau trauma pada saat prenatal, natal, dan postnatal. Selain itu, dapat disebabkan pada lingkungannya yang pada usia perkembangan bicara dan bahasa anak tidak memeroleh stimulus yang baik dari lingkungan. Anak-anak yang mengalami kesulitan tersebut dapat terjadi pada fonologis, semantik dan sintaksisnya. Dengan demikian, anak yang mengalami kesulitan dalam tranformasi sangat memerlukan kegiatan berkomunikasi. Salah satu gejala pada anak gangguan bahasa dan bicara, yaitu terdapat kesalahan pengucapan, baik dalam mekanisme pergerakan titik artikulasi maupun dalam pengucapannya. Penanganan yang dapat dilakukan untuk anak yang mengalami gangguan bahasa dan bicara adalah dengan melakukan terapi bicara, oral motorik, dan intonasi melodi.

\section{DAFTAR RUJUKAN}

Chaer, Abdul. 2009. Psikolinguistik Kajian Teoretik. Jakarta: Rineka Cipta.

Fatmawati, Suci Rani. 2015. Pemerolehan Bahasa Pertama Anak Menurut Tinjauan Psikolinguistik. Dalam Jurnal Lentera, Vol. XVIII (2):70_71.

Natsir, Nurasia. 2017. Hubungan Psikolinguistik dalam Pemerolehan dan Pembelajaran Bahasa. Dalam Jurnal Retorika, Vol.10 (1):25-27. 
Nurhidayati, Isti, dkk. 2013. Gangguan Bahasa dan Bicara. (Daring). Tersedia:

https://www.academia.edu/9012715/makalah_Gangguan Bahasa dan Bicara. (27/02/19)

Sastra, Gusdi. 2011. Neurolinguistik: Sebuah Pengantar. Bandung: Alfabet.

Tarigan, Hendy Guntur. 2008. Berbicara sebagai Suatu Keterampilan Berbahasa. Bandung: Angkasa

Yusuf, Syamsu. 2014. Psikologi Perkembangan Anak dan Remaja. Bandung: PT Remaja Rosdakarya. 